dent Lyndon Baines Johnson where his portfolio was education and health policy. While President Johnson's advisor, he was instrumental in the development and passage of the Elementary and Secondary Education Act, Medicare, the Higher Education Act, the Public Broadcasting Corporation Act, and many other policy initiatives of the Great Society.

Douglass Cater's associations with and contributions to higher education are equally impressive. Throughout his career he held visiting appointments and lectureships at the most prestigious institutions of higher education and research including Princeton University, Wesleyan University, UCLA, Stanford University, the University of Alabama, the Brookings Institution, and the Aspen Institute for Humanistic Studies. Most likely his crowning achievement in the area of education was his nineyear tenure in the 1980's as President of Washington College, the tenth oldest in the nation on the Eastern Shore of Maryland. Because of his tireless efforts raising funds for Washington College, this fine institution was able to survive and prosper when at times before his presidency, its future was uncertain at best.

Retirement in 1990 from Washington College, however, did not end Douglass Cater's association with higher education. After his return to Montgomery in 1991 he graciously accepted Auburn University at Montgomery's offer to become its first Distinguished Lecturer. For four years until the Summer of 1995, he informed and delighted AUM undergraduate and graduate students in his quarterly lectures on a variety of public policy issues. In an act of great generosity he donated 2500 books from his personal library to AUM in 1993.

Of Douglass Cater's six acclaimed books including one novel, none has had more impact on the discipline of political science than Power in Washington (1964). The volume is a classic in its analysis of policy formulation and development at the national level. The term "subgovernment" which characterizes the policy clusters that tend to dominate a distinct portion of the policy arena was coined by Douglass $\mathrm{Ca}$ ter. A great tribute to this gentleman of letters is that the term "subgovernment" is a part of the lexicon of public policy and many who use the term are unaware of the person who coined it.

Our sincerest sympathies are extended to his lovely wife, Libby, and their children and grandchildren. His legacy to them is one of remarkable accomplishments that will reflect posi- tively on the Cater name for many years to come.

We'll always miss Doug Cater, a dear friend and colleague.

Thomas Vocino

Auburn University at Montgomery

\section{Samuel Nelson Drew}

On August 19, 1995, Colonel Samuel Nelson Drew, the European affairs staff director at the National Security Council, was killed in a road accident while on a peace mission to Sarajevo. Colonel Drew received his Ph.D. in Government and Foreign Affairs from the University of Virginia. He had taught at the Air Force Academy and the National War College and had served as a national security fellow at Harvard University's John F. Kennedy School of Government. Colonel Drew had also completed a tour of duty at the U.S. Mission to NATO in Brussels and had served in the Joint Chiefs of Staff's strategic plans and policy directorate. He was the author of numerous works on national security and U.S. NATO policy, including "NSC-68: Forging the Strategy of Containment.' and "NATO from Berlin to Bosnia: TransAtlantic Security in Transition."

The news of Nelson Drew's untimely death deeply saddened those of us who shared so many rich and cherished times with him. At the memorial service at Fort Myer before his burial in Arlington National Cemetery, his friends and family remembered Nelson as representing the best of human traits-humility, honesty, decency, loyalty, courtesy, warmth, and genuine sincerity. President Clinton and National Security Advisor Anthony Lake shared their memories of Nelson as a trusted advisor and a creative young diplomat and peacemaker. Nelson Drew should also be remembered and honored as portraying the ideal qualities of the political science discipline.

The three of us spent our graduate years at the University of Virginia in close companionship with Nelson Drew. He was our study group leader, classroom foil, and steadfast friend. We would often congregate for lunch, delighting in his company. While Nelson laughed easily and heartily, he preferred to think deeply, but was never ponderous. His intellect was practical and sharp, and he was eager to engage it at any time. Scholarly discussions with Nelson were always serious but never pedantic.

Above all, Nelson was an eminently clearheaded, moderate, thoughtful, rational, and exceptionally practical political scientist. As was once observed of Professor Quincy Wright, "He kept the methodological horse firmly hitched to his substantive cart." Nelson concentrated his life's work on finding principled, yet workable, solutions to the most complex problems in the international arena. Characteristically, he embraced the challenge of trying to craft a solution to the age-old disputes of the Balkans. No one who knew him could be surprised that Nelson had progressed so swiftly through the ranks of the national security hierarchy, and we shared in the exhilaration that his new role produced. Thus, President Clinton's selection of Nelson to serve on an elite team of American peacemakers in Bosnia seemed a natural decision. This role-the serious, intelligent, articulate man of peace-was Nelson's forte. Few could have handled the unrelenting pressures and demands of such a delicate mission as adeptly and gracefully as Nelson Drew.

Nelson was an opinionated man, but never a zealot. He was not one to speak without thinking or to listen without concentrating. Indeed, perhaps unusual for the ranks of political scientists, Nelson stands out in our minds as both an eager and a formidable listener. He genuinely believed that everyone had something to contribute to his understanding of the world. He listened intelligently and attentively, and far more often than was strictly warranted, with genuine interest. One of our fondest memories since leaving graduate school is of Nelson seated squarely in the center of an audience when we delivered panel papers at political science conferences, urging us on with the quiet nod of his head or a supportive smile. Inevitably, Nelson would bound up to us as the panel ended to pat us on the back and compliment our performance. We always welcomed his response to the presentations for Nelson had an uncanny ability to comprehend any argument (even the most convoluted), clear away the intellectual debris, and restate the principal points so as to pinpoint their essence.

The political science profession often seems to save its most treasured rewards for the critics. The bright future that Nelson had in the profession was also tied to his critical mind. Once again, his approach was unusual in that he could be firm and persistent, yet humble and gentle. Rather than scoring debating points, Nelson preferred to give his counsel in such a way as to enlighten and change minds, not bruise feelings. He was not one to cut an in- 
tellectual opponent to ribbons with bombastic rhetoric. Nor would he tilt the playing field to give an advantage to the side of the argument he favored. Rather, Nelson's style was to disarm a troublesome questioner, to offer incisive comments with a sparkling wit, to take a clear-eyed look at all the facets of a problem and to convince a reluctant audience with sophisticated, organized, evenhanded, and thought-provoking analysis.

Finally, we should note that Nelson had a rare ability to share with others his excitement and fascination with international politics. He was one of those singular individuals who has the capacity to change forever his students and colleagues by his very example. His genuine warmth and affection, his personal and intellectual strength and clarity, his ironic sense of humor and endearing mannerisms always made us proud that he was part of our profession and that he was contributing his abundant talents to the cause of peace. In serving that cause he gave his life. In our grief, we are focusing on what Nelson gave to us, rather than what has been taken away by his tragic loss. He profoundly touched so many in political science. We will miss him always.

Julie Marie Bunck, University of Louisville

Michael Ross Fowler, University of Louisville

Barbara Ann Perry, Sweet Briar College

Colonel Nelson Drew had a truly unique and distinguished career in the U.S. Air Force during his more than twenty-three years of service as a soldier, scholar, and statesman. He served as an intelligence officer in Korea and Europe and as a political-military affairs officer on the NATO staff in Brussels, as a strategic planner on the Joint Staff in the Pentagon, and as the European affairs staff director on the $\mathrm{Na}$ tional Security Council. I would like to concentrate my remarks concerning Nelson to those years between 1980 1983 and 1986-1989 when he taught political science in the Department of Political Science at the Air Force Academy. Nelson's primary interests within the discipline were American government and U.S. national security policy. Not surprisingly, he taught and directed several of our courses which addressed these interests. Nelson also played a very major role in a curriculum review which occurred in the mid 1980s. This curriculum review was important because the department added a national security policy focus to both of our introductory courses on American government and international relations. No one was better qualified than Nelson to conceptualize and implement these revisions.

As important as his many administrative contributions were to this department, Nelson Drew truly distinguished himself as a role model for his students and the junior faculty members with whom he associated. He was a meticulous lesson planner and riveting platform instructor. One of Nelson's most lasting legacies will be the hundreds of former students who are now assuming positions of responsibility throughout the Air Force. He helped to create and develop their interests in political science, challenged them to think critically about domestic and international political issues, and monitored their progress beyond the classroom, encouraging each of them never to be satisfied with anything less than their best efforts. From personal experience, I know how effective Nelson was as a teacher and advisor because he was both for my daughter during her days as a student at the Academy. Nelson was also a superb supervisor. Some of his graduate school colleagues from the University of Virginia have already described his role as mentor to them when they participated on panels and delivered papers. He was an excellent mentor here as well, providing counsel when needed and always encouraging young faculty members to excel in the classroom and to participate in professional development. In October 1995, Sandy Drew brought their daughter to the Academy to attend an orientation program. While the Drews were here, I invited some of Nelson's former subordinates to come to the house to have dessert with Sandy. Without exception, each of these individuals is now part of the senior leadership in this department. I'm certain that Nelson would be very proud of the many contributions he made to each of these professors' development as scholars and leaders. Again, his legacy lives on.

After leaving the Academy, Colonel Drew pursued his passion for national security policy formulation and implementation. It is not always easy to make the transition from academic to policy advisor, but Nelson was consumed by the challenge and rose to meet it. During the summer of 1988 , he served temporarily on the National Security Council staff, and this experience convinced him that he wanted to become much more involved with the pol- icy process. While assigned to the NATO staff in Brussels, Nelson quickly established himself as a conceptual thinker who thrived on the most difficult policy issues confronting NATO as the Cold War concluded. Nelson was largely responsible for the development of the Combined Joint Task Force concept which NATO adopted in 1994 and will be employed to protect and enhance the peace process in Bosnia. In mid 1995, Colonel Drew moved to the NSC as the European affairs staff director, a position he had coveted since his 1988 stint on the NSC. He quickly became involved with the extremely difficult and demanding task of trying to formulate a plan to bring peace to the Balkans. Nelson immediately became known as a creative thinker who worked extremely long hours to become the NSC's primary strategist on Bosnia. It was for these contributions that President Clinton, Tony Lake, and others praised Colonel Drew at Arlington. The success recently achieved in negotiating a peace plan among the parties to the Bosnian dispute in Dayton is due in no small part to the efforts Nelson and his colleagues made toward that end. If peace is achieved, there is no better tribute to those who gave so much.

As a soldier, scholar, and statesman, Colonel Nelson Drew made a difference in each of these areas. For those of us fortunate enough to have known him, we are the better for that association. He was my friend of long standing, and I miss him, his sense of humor, his integrity, his sage counsel, and advice, but I know that his legacy will live on at the Academy and beyond.

William E. Berry, Jr. United States Air Force Academy

\section{Milan Hapala}

Milan Hapala, Carter Glass Professor of Government at Sweet Briar College, died on June 20, 1992, of a heart attack. Born and educated in Czechoslovakia, he attended Beloit College in Wisconsin in 1938 on a one-year exchange program. After his country was taken over by the Nazis, his father suggested that he stay in the United States. He received his BA from Beloit in 1940 and his MA in 1941 from the University of Nebraska. Professor Hapala became an American citizen in 1943 and served in the U.S. Army Air Corps in both the European and Pacific theaters during World War II. After the war he returned to his studies, earning 